\title{
East-African women's thoughts on stimulating the growth of their mid-scale enterprises
}

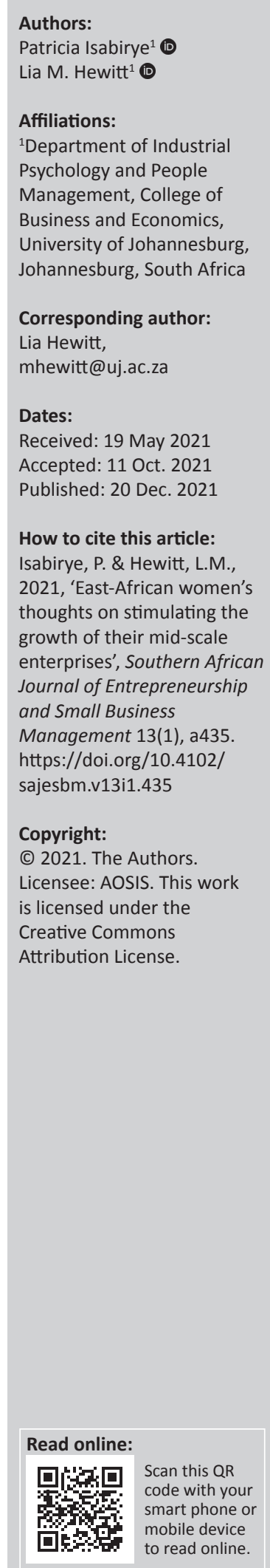

Background: Some of the obstacles to successful entrepreneurship in emerging economies are embedded in the internal operations and management of enterprises, especially women mid-scale enterprises. This includes the lack of effective strategies that promote the growth of women-owned mid-scale enterprises and their inclination towards necessity-based entrepreneurship, which greatly limits their growth potential.

Aim: The study explored the experience and know-how of strategies applied by three highprofiled women-owned mid-scale enterprises in East Africa to stimulate their business growth.

Methods: A qualitative research approach, using perspective seeking methods by applying unrestrictive semi-structured questioning was adopted.

Results: Findings suggest that women must embrace, recognise and own their internal aspirations and ambition to grow their mid-scale enterprise.

Conclusion: Women-owned mid-scale enterprises showed the need to map out their strategic growth plan and it must be built on a solid foundation to justify the need to grow for all stakeholders to buy into it.

Keywords: women-owned mid-scale enterprises; entrepreneurship; growth strategies; East Africa; stakeholders; growth plan.

\section{Introduction}

Small and medium enterprises (SMEs) are a vibrant force in most African economies, especially in relation to employment creation. They represent $90 \%$ of most enterprises whilst accounting for $63 \%$ of employment and contributing up to $50 \%$ of gross domestic product (GDP) in developing countries (Booysen 2015; Ezekiel et al. 2017; Gupta, Guha \& Krishnaswami 2013; Sriram \& Mersha 2010). World Bank data further suggest that SMEs in Africa contribute to $60 \%$ of all employment and as much as $40 \%$ to emerging economies GDP. This is further supported by the World Bank Report (2019) which stated that the entrepreneurship rate in sub-Saharan Africa is the highest in the world as of 2019; however, most entrepreneurs fail to progress beyond small-scale subsistence, which hinders their contribution to poverty reduction and prosperity. In addition, gender parity in the entrepreneurship sector in Africa is said to be as low as $0.59 \%$ according to the Global Entrepreneurship Monitor (GEM) (2017/2018) report (Singer, Herrington \& Menipaz 2018).

Women-owned business enterprises are smaller, less dynamic and tend to generate less income than their male counterparts (Potter, Halabisky \& Hannig 2016). Even with the presence of a higher majority of women entrepreneurs in sub-Saharan Africa than other regions (HallwardDriemeier 2013), these women still operate in traditional and informal sectors with minimal opportunities for expansion. Their enterprises do not yield sufficient profits and offer fewer possibilities to realise their potential (Hallward-Driemeier 2013; Nesbitt-Ahmed 2017).

Women entrepreneurs lack effective strategies that foster growth (Sriram \& Mersha 2010) and are usually inclined towards necessity-based entrepreneurship (Irene 2017; Odebrecht 2013; Potter et al. 2016). And yet, the strategic component and role of internal capabilities of African business enterprises have mostly been ignored as factors that shape business performance (Tvedten, Wendelboe \& Jeppesen 2012). In addition, the need to balance strategic practices within entrepreneurship has not been fully exhausted empirically, especially in the qualitative sense (Foss \& Lyngsie 2012; Kuratko \& Audrestch 2009; Kyrgidou \& Hughes 2010; Kyrgidou \& Petridou 2011; Schindehutte \& Morris 2009). 
Therefore, the main research question for this article is: What are the thoughts of three high-profile women, who own midscale enterprises in East-Africa, on stimulating the growth of their mid-scale enterprises?

\section{Research methods and design}

A social constructivist ontology is embraced by the authors with the notion that different people create meaning continuously in various ways through their interactions (Ponelis 2015; Saunders, Lewis \& Thornhill 2009; Soini, Kronqvist \& Huber 2011). The researchers' epistemology entailed a subjective approach towards understanding multiple experiences and insights derived from the participants (Camargo-Borges \& Rasera 2013; Creswell 2013; Howitt 2019; Ponelis 2015; Sutton \& Austin 2015). Axiology embraced the researchers' values and orientation towards 'women economic empowerment' and the role this played on how the research was conducted including relevance and choice of the research topic, philosophical paradigm and data collection approach (Creswell 2013; Ponelis 2015; Saunders et al. 2009).

A qualitative research approach was adopted using perspective-seeking methods (Gray 2014) by applying unrestrictive semi-structured questioning (Mackay \& Gass 2016) to generate varied views from a small but influential group of three high profile business women, located in East Africa, each considered as a case (Choy 2014). This was based on recurring experiences, which were both similar and different in nature (Creswell 2013, 2014; Dunn 2010; Hennink, Hutter \& Bailey 2010). Three participants, one per country, were selected to gather insights on the midscale growth phenomenon (Ridder 2017) using Yin's (2008) reasoning of replication. This was done by replicating procedures in each of the three participants whilst describing them in details and taking note of their unique and similar circumstances.

Further to this, the authors adopted a narrative literature review approach, which focused on analysing and summarising existing evidence (Arshed \& Danson 2015) to gather theoretical knowledge on mid-scale growth issues to enrich the findings (Bryman 2008; Howitt 2019; Saunders et al. 2009; Taylor, Bogdan \& DeVault 2016).

The study population consisted of perceived successful women entrepreneurs in Kenya, Uganda and Tanzania. These countries were selected because of their unique women business profiles, promising entrepreneurial status and overall potential for economic growth within their respective regions. Uganda has been acclaimed for its high number of women entrepreneurs globally (Mastercard 2017; Ngugi 2017), Kenya is lauded for the government's efforts to promote women entrepreneurship through affirmative actions (Rugene 2015; Wanjala 2018) and the government of Tanzania's transition from socialism to private enterprises has seen women flourishing within the entrepreneurship sector (Edwards 2012; Verhoef 2017).
A deliberate and judgemental sampling process was applied, which included a small, non-random and purposively selected group of three high-profile women who own midscale enterprises, one from Kenya, Tanzania and Uganda, each considered as a case. These women were carefully selected because of their expertise and lengthy experience on women entrepreneurship issues (Howitt 2019; Mason 2010; O’Reilly \& Parker 2012; Panneerselvam 2018; Uwe 2015). The idea was to target mid-scale enterprises owned by women who would sufficiently answer the research question and whose views would be considered as influential in sharing their thoughts on growth strategies they adopt, based on their lengthy experience in leading their respective mid-scale enterprises. Therefore the researchers were realistic, flexible and rational when determining this sample (Howitt 2019; Jette, Grover \& Keck 2003; O’Reilly \& Parker 2012).

The distinct narrative voice of the women was amplified to gather insights from them on how their business operations have improved through the use of the growth strategies they applied (Creswell 2007; Kendall \& Kendall 2012; Taylor et al. 2016; Wang \& Geale 2015).

Studies revealed that qualitative research findings may not be that accurate and are less likely to be representative or generalised because of the restrictive scope of the study (Bryman 2008; Choy 2014; Dunn 2010; Howitt 2019). The small sample usually adopted during qualitative studies is not likely to represent the wider context as was the case with this study. However, the authors applied Williams (2000:215) notion of 'moderatum generalisations' which points out that the primary focus of an enquiry in this case exploring how growth strategies can be adopted from perceived successful women entrepreneurs in East Africa represents a sub-section of a larger setting. This meant that data from the three participants represented the wider entrepreneurial setting in Africa to some extent. Therefore, feedback from the three participants was useful in responding to questions related to the study and to complement available literature, which was amongst the key focus of this article. Table 1 presents an overview of the three participants profiles.

Primary data collected were organised and summarised to answer the research question (Glaser \& Laudel 2013). Thematic analysis was used to analyse data by examining and constructing major themes during which unanticipated insights were derived (Creswell 2013; Haslam \& McGarty 2014; Howitt 2019; Thomas 2003). Discourse analysis entailed scrutiny to language (Haslam \& McGarty 2014; Howitt 2019), applied as a form of symbolic interaction (Howitt 2019) to deepen understanding of aspects of the data, using language to form meaning in a creative, active and influential manner (Haslam \& McGarty 2014). The authors generated five concrete themes using thematic analysis. Coding was used to categorise significant aspects of the data using colour coding (O'Connor \& Joffe 2020). The study was designed and executed morally in a manner that affects society positively and took note of ethical considerations that need to be 
TABLE 1: An overview of the participants' profile.

\begin{tabular}{|c|c|}
\hline Variable & Description \\
\hline \multirow[t]{2}{*}{ Sample } & Three (3) women mid-scale entrepreneurs \\
\hline & Kenya (1), Tanzania (1), Uganda (1) \\
\hline \multirow[t]{15}{*}{ Profiles } & Founder and CEO of a Brand Strategy and Design Company in Kenya \\
\hline & Brand Strategy and Communications Industry \\
\hline & More than 20 years in business \\
\hline & Approximately 1.5 million USD annual turnover \\
\hline & 18 Permanent staff +50 associates and partners \\
\hline & Founder of a spa and later co-owner of a hotel resort in Tanzania \\
\hline & Hospitality industy \\
\hline & More than 10 years in business \\
\hline & Approximately 650000 USD annual turnover \\
\hline & More than 20 employees \\
\hline & Co-owner of an interior design and furnishing company \\
\hline & Furniture and interior design company \\
\hline & More than 25 years in business \\
\hline & Approximately 4-5 million dollars annual turnover \\
\hline & Approximately 87 staff in total \\
\hline \multirow[t]{5}{*}{$\begin{array}{l}\text { Criteria for } \\
\text { selection }\end{array}$} & $\begin{array}{l}\text { Women mid-scale entrepreneurs with over } 10 \text { years' experience } \\
\text { owning and running a business }\end{array}$ \\
\hline & Capital turnover of above US $\$ 100000$ \\
\hline & More than 20 employees \\
\hline & Capital investments over US $\$ 100000$ \\
\hline & Willingness and ability to participate \\
\hline
\end{tabular}

adhered to for any research study specifically (Bryman 2008; Saunders et al. 2009).

Trustworthiness was critical in this study and was applied (Johnsson et al. 2014) by ensuring that rigour and transparency were enforced during coding in data analysis through the thematic structure developed (O'Connor \& Joffe 2020). Credibility was applied by initially familiarising with all participants related to this study before the interview phase. This entailed reaching out to other entrepreneurial experts to seek advice about the selected participants' credibility followed by establishing the appropriate trust and rapport with all participants. Researcher bias was avoided by selecting all participants on an indiscriminate basis without any prior acquaintances with the authors. The multiple participant approach captured different participants' voices, which provided diverse views and perceptions critical in generating varied knowledge that represents the wider East African setting (Fusch \& Ness 2015; Korstjens \& Moser 2018; Lincoln \& Guba 1985; Loh 2013; Shenton 2004; White, Oelke \& Friesen 2012).

\section{Literature review}

This section presents a narrative literature review, which has been applied to unpack intellectual content (Snyder 2019; Walliman 2011) on women entrepreneurship, the concept of growth, some useful growth-oriented strategies and a theoretical framework that explains two relevant theories of growth and their applicability to the women entrepreneurship phenomenon.

\section{Women entrepreneurship}

Studies reveal that women entrepreneurship is critical to global social and economic development (Ascher 2012) and allows women to diversify other sources of income, which enables them to undertake additional responsibilities (Lain 2016). Women in Africa are more active in economic activities than those from other parts of the world (AfDB 2015) and are capable of sharing knowledge with their staff whilst building strong relationships (Odebrecht 2013; Shmailan 2016). Investing in women entrepreneurship translates into good citizenship, a flourishing entrepreneurship sector and a robust economy (Lain 2016; Meyer 2018; NesbittAhmed 2017; Ramaswami \& Mackiewicz 2009). However, women participation in various economies is still inadequate (Singer et al. 2018) with limited representation and a focus on smaller and less dynamic business enterprises (Ascher 2012; Potter et al. 2016; Sriram et al. 2010). Therefore, it is imperative to reduce this gender gap by introducing the appropriate mechanisms that can ensure an inclusive entrepreneurial space with some degree of gender parity (Singer et al. 2018). Some of these mechanisms include strategies for the growth of women-owned mid-scale enterprises to achieve improved performance and sustainable progress using a range of tools, approaches and techniques (Arshed, McFarlane \& MacIntosh 2016; McGoldrick 2002).

\section{Growth as an essential factor}

Studies revealed that growth is an essential indicator of a thriving business enterprise, reflected in the amount of revenue generated, value addition, expansion in terms of volume, position in the market, product quality, customer favour, size of mid-scale enterprise, future growth plans, and most of all the quality of interaction between the internal and external business environment (Arshed et al. 2016; Fernando 2011; Gupta et al. 2013; Mateev \& Anastasov 2010). Growth is usually displayed by internal finances, increased sales, employee numbers, assets, profits and multiple strategies (Achtenhagen, Ekberg \& Melander 2017; Gupta et al. 2013; Mateev \& Anastasov 2010). The growth of an enterprise is, therefore, determined by successful market penetration and customer focus, amount of capital required during start-up, growth strategy of the enterprise, availability of human capital and other resources (Korunka et al. 2011). It is therefore imperative to understand how best women entrepreneurs can ensure that their mid-scale enterprises remain stable by using the relevant growth strategies to strengthen their respective enterprises so that they can withstand demanding internal and external forces (Achtenhagen et al. 2017; Časas, Kavaliauskė \& Dambrauskaitė 2011; Fernando 2011; Shirokova, Bogatyreva \& Beliaeva 2015).

\section{Useful growth-oriented strategies}

The increasing need for inclusive, smart and responsible growth in mid-scale enterprises necessitates concrete efforts in the form of innovative strategies (Kronz, Sinar \& Mitchell 2014). This includes progressive technologies, increased stakeholders engagement, multiple efforts around cost reduction and creation of high quality teams (Hannum et al. 2011; Kronz et al. 2014; PWC 2014; Ungerer, Ungerer \& Herholdt 2016). Knowledge-based entrepreneurship that focuses on creativity and innovation (Arshed et al. 2016; Seo \& Lee 2019) and dwells heavily on investing in technology, 
research and development are key success factors in gaining competitive edge and growth (Gupta et al. 2013; Kuratko \& Audrestch 2009; Leminen \& Westerlund 2012; Yang et al. 2014).

Change oriented strategies that focus adequately on the bigger picture incorporate multiple actors within the wider business environment and useful internal leadership dynamics (Mazzarol 2014). These focus on growth potential for better job creation and innovation whilst embracing growth aspirations by streamlining internal processes strategically to drive growth (Irene 2017; Leminen \& Westerlund 2012).

Sustainability strategies ensure that needs of present and future generations are equally met and guarantee long-term entrepreneurial success (Akhtar et al. 2015). This includes processes like business model innovation (Charan 2017; Yang et al. 2014) that focus on solid management, strategic thinking, flexibility, predicting future opportunities and maintaining linkages that foster positive change by promoting smooth internal functions within mid-scale enterprises (Arshed et al. 2016; Bolden \& Kirk 2009; Fernando 2011; Kezar 2004; Kuratko 2007; Leminen \& Westerlund 2012; Uhl-Bien 2006; Ungerer et al. 2016).

Market penetration and expansion is another useful growthoriented strategy. This includes knowledge-based innovations, improved competencies, relational tendencies and other mechanisms to deal with local and foreign market dynamics and subsequent customer retention to influence competitiveness as a fundamental growth-oriented strategy (Arshed et al. 2016; Booysen 2015; Crick, Kaganda \& Matlay 2011; Dragnić 2014; Joseph \& Unnikrishnan 2016; Heikkilä, Bouwman \& Heikkilä 2018; Nieuwenhuizen 2014; Seo \& Lee 2019; Wheeler, Ibeh \& Dimitratos 2008).

The culmination of growth-oriented strategies within midscale enterprises focuses on a detailed, structured, flexible and regularly updated plan of action known as the business strategy (Bora, Borah \& Chungyalpa 2017; Nieuwenhuizen 2014). This plan of action is designed to determine market position, conduct internal operations, attract and retain clients, maintain competitiveness, achieve organisational objectives and evaluate overall performance, a critical aspect of the entrepreneurial growth process (Arshed et al. 2016; Dragnić 2014; Gupta 2018; Heikkilä et al. 2018; Nieuwenhuizen 2014; Rick 2018; Vining 2011).

\section{Relevant theories of growth}

The stratified systems theory (SST) suggests that high level of cognitive complexity translates into learning and assimilates acquired information into decision-making (Hewitt \& Janse Van Rensburg 2018; Lundberg \& Richards 1972). This equips people who harbour such attributes with the capacity to analyse and offer solutions to problems and complex situations, and adjust to situations regardless of their hierarchy or level within the organisation and to be more strategic in thinking. This is appropriate when designing winning strategies for mid-scale enterprises particularly within the volatile context in which they operate to enable them to survive and grow especially in emerging economies (Jaques \& Clement 1991; Unger et al. 2009; Yuki 2002). Succeeding repeatedly during strategic interactions requires analytical thinking and what has been labelled as theory of mind, which is one's ability to comprehend other people's motives and actions and out-manoeuvre them where necessary (Coricelli \& Nagel 2009; Ohtsubo \& Rapoport 2006). These authors deciphered the organisational behaviour of perceived successful women entrepreneurs including their cognitive and intellectual abilities, how they assimilate information and adopt theory of the mind capabilities when managing their mid-scale enterprises including constructing the essential strategies for growth.

The relational theory postulates that effective coordination across products, functions and geographical lines is essential for growth (Sniukas, Lee \& Morasky 2016). Successful organisations come together as one to implement strategies. This form of collaboration links geographical, traditional and other boundaries for a common good. Global competition and success within global markets in emerging economies calls for shared responsibilities in the form of team work both in and out of the work place. This will promote improved innovation and productivity which leads to growth (Achua 2010). Growth-oriented strategies include relational tendencies (Crick et al. 2011) that are central to how women conduct leadership (Bolden \& Kirk 2009; Kezar 2004; Uhl-Bien 2006). As Isenberg (2011) pointed out, the main driving force for the success of entrepreneurship is the level of interactions amongst variables working together, which makes women entrepreneurs well suited to engage in entrepreneurship.

\section{Findings and discussions}

Findings depict how the women entrepreneurs targeted during this study used information as intellectual capital and managerial capability to design strategies for growth as reflected in the SST (Hewitt \& Janse van Rensburg 2018; Jaques \& Clement 1991; Lundberg \& Richards 1972; Unger et al. 2009; Yuki 2002). The element of cognitive complexities (Hewitt \& Janse van Rensburg 2018; Lundberg \& Richards 1972; Unger et al. 2009) was useful in enhancing understanding on how information can be used to deal with the recurring internal gaps faced by women-owned mid-scale enterprises to strengthen their ability to foster growth of their enterprises.

Five principal themes were generated in this study, which portray the need for a significant level of internal and external engagement with stakeholders when embarking on the growth path and ultimately designing the necessary strategies for growth (Achua 2010; Crick et al. 2011; Isenberg 2011; Sniukas et al. 2016). This fosters sustainable relationships, networks and linkages that feature in successful growth interventions (Fernando 2011; Leminen \& Westerlund 2012; Mazzarol 2014; Nieuwenhuizen 2014; Seo \& Lee 2019), and re-emphasises elements of the relational theory (Achua 2010; Crick et al. 2011; Isenberg 2011; Sniukas et al. 2016), which is pivotal to how women entrepreneurs conduct their 
leadership responsibilities (Bolden \& Kirk 2009; Kezar 2004; Uhl-Bien 2006). The themes culminate into the thoughts of these women on strategies for growth, which can be adopted by other women who own or manage mid-scale enterprises within the wider African setting (Haslam \& McGarty 2014).

\section{Theme 1: Embrace a growth attitude}

A very useful strategy that should be adopted by womenowned mid-scale enterprises embarking on the growth path is the need to embrace a growth attitude as part of the comprehensive growth plan. This can be done by acknowledging internal growth aspirations and ambitions which is a significant step when dealing with growth matters. This growth attitude was determined through the profiles of the selected mid-scale enterprises targeted for this study (Table 1), which reflect some of the fundamental growth indicators as suggested in the reviewed literature (Achtenhagen et al. 2017; Arshed et al. 2016; Gupta et al. 2013; Korunka et al. 2011). These distinct growth-oriented characteristics as well as a detailed account of their dynamic internal business environment depicted during the interviews portray the participants' growth attitude without which growth would not manifest. The internal practices that were shared by women entrepreneurs pointed out various experiences that reaffirm that they own and manage growth-oriented enterprises.

The need to first and foremost acknowledge and embrace growth which is the first step in attempting a fulfilling growth journey was suggested by a participant who co-owns a family business that started small and grew organically. She emphasised that:

'to have a business that is in growth stage means that you are doing something right to begin with so give yourself a clap'. (Participant A, female, above 40 years old)

Another participant denoted that 'by 2011, I had a very big name in Country $X$ that encouraged other saloons to open up massage parlours' (Participant B, female, above 40 years old) and she deliberately focused on infiltrating the market by adopting a range of initiatives including engaging in television and radio talk shows, conducting seminars, training people and engaging women and men's groups to create awareness about the importance of massages. In addition, the spa that she currently runs at her hotel resort is said to have grown and: 'became the name of Island $x x$ with, best reviews on trip advisor'. She added that '...you know last year we got the best reviews, we were the number one reviewed hotel on the island' (Participant B, female, above 40 years old).

One participant suggested that growth may be reflected in increased product proposition, increased geographies and the presence of new partners or ventures. She stated that her enterprise has partners in Rwanda, Uganda and Tanzania. All participants confirmed that their mid-scale enterprises are growth-oriented and that a growth attitude is entrenched in their internal culture and that they have considerable experience in defining their paths towards growth.

\section{Theme 2: Adopt growth holistically}

An inclusive and sustained growth plan is a principal strategy in the comprehensive growth process. This growth plan should be doable, realistic, deliberately designed, for a specific duration and within a particular period of time. It should also incorporate the buy-in, the consensus and efforts from all relevant stakeholders especially the staff, which highlights the aspects of the relational theory that emphasises collaboration (Achua 2010; Crick et al. 2011; Isenberg 2011; Sniukas et al. 2016). The holistic approach to growth will be made possible through organised growth-oriented actions, which can effectively be determined within a robust and dynamic internal business environment. These are all pertinent in reinforcing the growth process, making it operational, successful and sustainable as several authors on growth and growth-oriented strategies postulate (Arshed et al. 2016; Crick et al. 2011; Heikkilä et al. 2018; Korunka et al. 2011; Mazzarol 2014; Leminen \& Westerlund 2012; Rick 2018; Seo \& Lee 2019).

Hence, such a holistic approach will ensure that the design and implementation of the growth plan are sustainable, rewarding, with a sense of ownership by all involved and illustrate principles of the relational theory that promotes relationships and coordination in and out of the work place (Achua 2010; Crick et al. 2011; Isenberg 2011; Sniukas et al. 2016).

Participants reiterated that the process of embarking on a sustainable growth plan should be well resourced, appropriately understood, substantially justified and fully embraced by all relevant stakeholders, which depicts literature on sustainability strategies (Akhtar et al. 2015).

All three participants expressed the need to appreciate growth strategies holistically, which should be entrenched within internal culture and must attract commitment from the entire organisation to register success. They detailed their perceptions about how women mid-scale entrepreneurs should approach the growth process as rationally and as practically as possible, which all formed a major segment in the holistic operationalisation of the growth process.

One participant advised women mid-scale entrepreneurs to start their entrepreneurial journey with a 'big idea' which is what will sustain their motivation for growth and to maintain their impetus for the same. This supports literature on the need for change oriented strategies that embrace the big picture (Mazzarol 2014). Another participant gave concrete suggestions about first of all answering questions related to whether they want to grow and if that is the case, they should be in a position to answer subsequent questions related to how this growth will be managed and effected including any benefits, risks and opportunities related to this growth. According to her:

\footnotetext{
'...[A] women entrepreneur must have the courage to answer to the question of do I want to grow? They need to define in what ways do I want to grow? And then they must answer to
} 
the question of what are the benefits, risks and what threatens my growth, and where are the opportunities of growth? And then this growth must be translated into financial benefits, reputational equity, benefit to the employees and the dividends that the growth would present to the investors or shareholders'. (Participant C, female, above 40 years old)

She recommended the need for organisational commitment and buy-in to register success of the growth process, which represent the collaborative aspect of the relational theory (Achua 2010; Crick et al. 2011; Isenberg 2011; Sniukas et al. 2016). She also suggested the need to assess organisational attitudes and energy towards this growth, together with resources adequacy, timing, value proposition and psychological preparedness. All this points towards a holistic adoption of growth, which should be internalised as adequately as possible to ensure sustainability (Akhtar et al. 2015).

One participant engaged with colourful language by alluding the growth process to watering a flower so that it nourishes and blossoms, which was captured during discourse analysis to depict meaning by portraying the love and dedication she has for her business enterprise (Haslam \& McGarty 2014; Howitt 2019).

She applied the phrase, 'if you love a flower so much you will not cut it, you will water it to keep blossoming' to depict the love for her hotel resort. This is a motivational factor to devote time and energy to its growth like one would do to a flower. This participant beckoned women mid-scale entrepreneurs with a growth mindset to display love for their enterprises and use this love as motivation for a fulfilling growth process, which also reflects a holistic approach to growth.

\section{Theme 3: Meaning of growth strategies}

Meaning of growth strategies was a common theme extracted according to all the participants' understanding and experiences. This theme is useful in outlining the intricacies that are crucial when determining and further implementing growth strategies. Participants revealed that although they currently lack a written down growth strategy document or model at the moment, they are likely to adopt one in the long run. One participant defined growth strategies as:

'a strategy on how one needs to implement a plan of action, how you intend to achieve your higher level of growth, or market, or service'. (Participant B, female, above 40 years old)

Another participant compared it to an instrument that informs their growth hence, although a framework document in this regard may be absent in her mid-scale enterprise, she still has a mechanism in place for driving growth. The design of growth strategies was also described by a participant as:

'a process through which a business will engage or implement in order to grow revenue, grow reputation, grow profits, grow talent or human resources and grow return on investment for shareholders'. (Participant C, female, above 40 years old)
These meanings were integrated in the development of this theme, which reaffirms the need for women-owned midscale enterprises to fully understand the meaning of growth strategies as part of their design and implementation to ensure their sustainability (Akhtar et al. 2015).

All stakeholders need to understand the meaning of growth when attempting to drive growth of their mid-scale enterprises to ensure sustainability (Akhtar et al. 2015) and have the necessary impact within the mid-scale enterprise. If meaning of the adopted growth strategy is understood as succinctly as possible, the design and implementation can be justified, it can be embraced, be owned and managed, and become a fulfilling growth process for all. This captures the coordination and collaborative elements of the relational theory which are essential for growth (Achua 2010; Crick et al. 2011; Isenberg 2011; Sniukas et al. 2016).

\section{Theme 4: Justification for growth strategies}

Theme four highlighted the need to justify the presence of a growth strategy. This justification should be sufficiently understood by all stakeholders involved when focusing on sustained growth and is useful when implementing and operationalising the comprehensive growth plan. All three participants acknowledged the justification for growth strategies and shared their perceptions.

The participant from Kenya recommended the need for a well rationalised growth strategy that should be endorsed, justified and well understood at the organisational level. She gave some details about the importance of a growth strategy framework stating that this is necessary because it establishes order, structure and discipline in managing growth. She added that 'poorly managed growth is a risk' (Participant C, female, above 40 years old) which can wipe out an investment. Therefore, 'growth must be carefully managed at all times' (Participant C, female, above 40 years old). She suggested that the lack of well-managed growth tends to fail the customers, employees as well as the shareholders. However, the presence of a growth framework will minimise risks from resources, reputation, market shares and the future, whilst presenting order, structure and efficiency (Arshed et al. 2016; Dragnić 2014; Gupta 2018; Heikkilä et al.2018; Nieuwenhuizen 2014; Rick 2018).

The participant from Tanzania was honest that she 'never strategises', but she 'deals with situations as they come head on...' (Participant B, female, above 40 years old) meaning as they arise haphazardly but she did agree that growth strategies are necessary and together with the participants from Uganda and Kenya reiterated that structured growth is useful and essential. The participant from Uganda believes 'a written down growth strategy model which you can follow and be accountable to could be a good thing to have' and confessed that 'I don't have it and the business is running. I think going forward we'll get it' (Participant A, female, above 40 years old). She added that a structured growth strategy model may exist within 
established multi-nationals like Coca Cola and Multi Choice but it is not the case with an average women entrepreneur.

\section{Theme 5: Solid approaches to growth}

A solid approach to growth is desired by these women entrepreneurs and lends support to what is postulated in the literature that a solid business strategy forms part of growthoriented strategies (Arshed et al. 2016; Bora et al. 2017; Dragnić 2014; Gupta 2018; Heikkilä et al. 2018; Nieuwenhuizen 2014; Rick 2018; Vining 2011). Concrete internal actions and efforts should be deliberately designed to match the external environment (Hewitt 2017), implemented and constantly updated for internal improvement and resultant growth. These are necessary as participants suggested, and should be in line with enterprises' vision, mission and applicable within the industry, geographical settings, and national and global priorities.

Participants revealed the need for a combination of factors and concerted efforts all of which when brought together support the development of deliberately designed growth approaches that are evidently useful in the growth process for women-owned mid-scale enterprises. All participants confirmed that they do have existing approaches in place which are not captured in a framework document. However, they do perform a number of measures, activities and practices, which contribute to the growth of their respective mid-scale enterprises. Some of these activities are unique to their specific industries but are useful components in strengthening the growth process.

Enhancing growth requires improved marketing and pricing, diversification, adopting the digital agenda, creativity, functional relationships, adequate knowledge of the external environment and the ability to forecast or pre-empt the unknown.

This supports the viewpoint advanced by some authors on the importance of innovation (Arshed et al. 2016; Seo \& Lee 2019) and change oriented strategies (Mazzarol 2014) for growth. Participants unpacked some tailor made internal practices that are in line with their core business to grow, which is relevant to their particular industry, their external and internal environment, and ultimately to their customers.

\section{One participant described their diversification strategy:}

' $[A]$ nd then also maybe you look at diversifying... The easiest thing to do in Uganda is real estate...we also diversify in product...we are looking into manufacturing, so gradually we are looking into doing our own kitchens and wardrobes and doors. ..... see that we get to the client at the earliest point possible'. (Participant A, female, above 40 years old)

According to Mazzarol (2014), these are diversification oriented strategies that focus on the bigger picture and are necessary for growth and survival. The same participant described their efforts to purely digitalise their enterprises as another significant approach to grow the business. According to another participant, the researchers' attempt to design some essential strategies for growth, prompted her to think through her growth process consciously and share some of their targeted approaches related to growth and sustainability

'...with you trying to put something on paper I can say where the growth strategy is involved, for example you need to have your marketing...I need to consider the pricing...have special meals because it's a hotel...there is creativity....and then how you cooperate with the external suppliers in order to make the customer feel good'. (Participant B, female, above 40 years old)

These are echoed by Arshed et al. (2016) and Booysen (2015)'s insights on the importance of market penetration and customer retention strategies.

\section{Conclusions and recommendations}

The study concludes with the observation that the concept of growth and the meaning of it is a holistic and ongoing internal transformation process that requires various deliberately designed and inter-linking strategies to realise success. Part of this process, firstly, includes internalising and embracing a personal desire to grow their mid-scale enterprises. Secondly, as a requirement for success, the adoption of the idea to embark on growth strategies by all stakeholders must be embraced. Thirdly, the meaning of the growth strategy and where it will lead the enterprise, and what will be required must be understood by all stakeholders within the enterprise. Fourthly, the justification to drive growth must be built on a solid foundation to ensure commitment from all. Lastly, clear focus is required by participants on the type of strategies that are to be pursued.

These processes should all be taken into consideration, internalised and unpacked comprehensively by all relevant stakeholders with the women entrepreneur at the helm. Such intricacies within the growth design and implementation process should be applied to various geographical settings using the correct operational approach to ensure that they are understood and accepted in an inclusive manner.

Succession planning and empowering of employees in strategic areas were not discussed, however, Hewitt and Janse Van Rensburg (2018) warned that mid-scale enterprises that are on a growth trajectory must, from an early stage, plan for succession, or the business will come to an abrupt end or stifle its own growth because of the owner working 'in' the business and not 'on' the business. If the owner is not able to run the business anymore, will the business still be operational? If not, their never was a business (Hewitt \& Janse Van Rensburg 2020). A concern is the lack of documented growth strategies, which makes it difficult for staff and other stakeholders as the growth map resides with the owner. These owners become directive in terms of what they want and how it must be done, with little room for stakeholders to contribute meaningfully to the growth of the enterprise as they lack the vision.

\section{Contributions and limitations}

The study contributes to the narrative on the continuing empowerment of African women, unpacking their endeavours 
to grow their mid-scale enterprises. The small sample size of this study only provides insights into the lived experience of three African women, each in their own country, who made a success of their mid-scale enterprises.

\section{Areas of future research}

An area of interest includes the lack of mapped out physical strategic growth plans. The lack of succession planning and need to justify to employees why the business must grow before such a strategy can be driven by the owner.

\section{Acknowledgements Competing interests}

The authors declare that they have no financial or personal relationships that may have inappropriately influenced them in writing this article.

\section{Authors' contributions}

P.I. conducted the primary research and data gathering. L.M.H. assisted with supervision, conceptualisation and interpretation and overall structure of article.

\section{Ethical considerations}

Ethical clearance was granted by the Department of Industrial Psychology and People Management in the College of Business and Economics at the University of Johannesburg. Ethical Certificate received from IPPM2018-269(D).

\section{Funding information}

The authors received no financial support for the research, authorship and/or publication of this article.

\section{Data availability}

The data that support the findings of this study are available from the corresponding author, L.M.H., upon reasonable request.

\section{Disclaimer}

The views and opinions expressed in this article are those of the authors and do not necessarily reflect the official policy statement or position of any affiliated agency of the authors, and the publishers.

\section{References}

Arshed, N. \& Danson, M., 2015, 'The literature review', in K. O'Gorman \& R. Maclntosh (eds.), The Global Management Series, Research Methods for Business \& Management, 2nd edn., Goodfellow Publishers Ltd, Oxford.

Achtenhagen, L., Ekberg, S. \& Melander, A., 2017, 'Fostering growth through business development: Core activities and challenges for micro-firm entrepreneurs', Journal of Management \& Organization 23(2), 167-185. viewed 20 September 2018, from http://hj.diva-portal.org/smash/get/diva2:1081256/FULLTEXT01.pdf.

Achua, L., 2010, Leadership, theory, application and skill development, South Western Learning, Mason.

African Development Bank (AfDB), 2015, African women: An agenda for action Africa gender equality index 2015, viewed 29 May 2019, from https://www.afdb. org/fileadmin/uploads/afdb/Documents/Publications/African_Gender_Equality Index_2015-EN.pdf.
Akhtar, C.S., Ismail, K., Ndaliman, M.A., Hussain, J. \& Haider, M., 2015, 'Can intellectual capital of SMEs help in their sustainability efforts?', Journal of Management Research 7(2), 82-97. https://doi.org/10.5296/jmr.v7i2

Arshed, N., McFarlane, J. \& Maclntosh, R., 2016, The global management series, Enterprise and its business environment, Goodfellow Publishers Ltd., Oxford.

Ascher, J., 2012, 'Women entrepreneurship - An appropriate response to gender discrimination," Journal of Entrepreneurship, Management and Innovation (JEMI) 8(4), 97-114

Bolden, R. \& Kirk, P., 2009, 'Surfacing new understanding through leadership development', International Journal of Cross-Cultural Management 9(1), 69-86.

Booysen, K., 2015, Dynamics of entrepreneurship, Juta and Company, Cape Town.

Bora, B., Borah, S. \& Chungyalpa, W., 2017, 'Crafting strategic objectives: Examining the role of business vision and mission statements', Journal of Entrepreneurship and Organisation Management 6(1), 205. https://doi.org:10.4172/2169-026X. 1000205

Bryman, A., 2008, Social research methods, 3rd edn., Oxford University Press, Oxford.

Camargo-Borges, C. \& Rasera, E.F., 2013, 'Social constructionism in the context of organisation development', Dialogue, Imagination, and Co-Creation as Resources of Change, April-June 20133(2), 1-7. https://doi.org/10.1177/2158244 013487540

Časas, R., Kavaliauskè, M. \& Dambrauskaitè, V., 2011, 'Impact of external business environment factors on internationalization of Lithuanian born global companies' Transformation in Business and Economics 90(3), 120-135. https://doi. org/10.15388/Ekon.2011.0.931

Charan, R., 2017, 'How high potential leaders can master the macro environment', Leader to Leader 2017(85), 31-36. https://doi.org/10.1002/ltl.20303

Choy, L.T., 2014, 'The strengths and weaknesses of research methodology: Comparison and complimentary between qualitative and quantitative approaches', IOSR Journal of Humanities and Social Sciences (19) 4. Version III, 99-104.

Coricelli, G. \& Nagel, R., 2009, 'Neural correlates of depth of strategic reasoning in medial prefrontal cortex', Proceedings of the National Academy of Sciences 106(23), 9163-9168.

Creswell, J.W., 2007, Qualitative inquiry \& research design, Sage, Thousand Oaks, CA.

Creswell, J.W., 2013, Qualitative inquiry \& research design, choosing among five approaches, 3rd edn., Sage, Thousand Oaks, CA

Creswell, J.W., 2014, Research design, qualitative, quantitative \& mixed methods approaches, 4th edn., Sage, Thousand Oaks, CA.

Crick, D., Kaganda, D.E. \& Matlay, H., 2011, 'A study into the international competitiveness of low and high intensity Tanzanian exporting SMEs', Journal of Small Business and Enterprise Development $18 \mathrm{https} / / /$ doi.org/10.1108/14626001111155727

Dragnić, D., 2014, 'Impact of internal and external factors on the performance of fastgrowing small and medium businesses', Journal of Contemporary Management Issues 19(1), 119-159.

Dunn, D.S., 2010, The practical researcher: A student guide to conducting psychological research, 2nd edn., Wiley-Blackwell, Oxford.

Edwards, S., 2012, Is Tanzania a success story? A Long-term Analysis (No. w17764), National Bureau of Economic Research, Cambridge.

Ezekiel, M., Micheal, E., Virginia, K. \& Andah, R.A., 2017, 'Conceptualizing small and medium scale enterprises; It's implications to the economic growth of Nigeria 1999-2016', International Journal of Managerial Studies and Research 5(8), 58-76, viewed 24 May 2019, from https://www.arcjournals.org/pdfs/ijmsr/v5i8/7.pdf.

Fernando, A.C., 2011, Business environment, Pearson Education, Delhi.

Foss, N.J. \& Lyngsie, J., 2012, 'Strategic entrepreneurship: An emergent approach to firm-level entrepreneurship', in D. Hjorth (ed.), Handbook of organizationa entrepreneurship, pp. 208-225, Edward Elgar Publishing Ltd, Cheltenham.

Fusch, P.I. \& Ness, L.R., 2015, 'Are we there yet? Data saturation in qualitative research', The Qualitative Report 20(9), 1408-1416, viewed 29 August 2017, from http://www.nova.edu/ssss/QR/QR20/9/fusch1.pdf.

Glaser, J \& Laudel, G, 2013, 'Life without coding: Two methods for early-stage data analysis in qualitative research aiming at causal explanations', Quality Socia Research 14(2), Art. 5, viewed 29 August 2017, from http://www.qualitativeresearch.net/index.php/fqs/article/view/1886/3528

Gray, D., 2014, Doing research in the real world, 3rd edn., Sage, London.

Gupta, P.D., Guha, S. \& Krishnaswami, S.S., 2013, 'Firm growth and its determinants', Journal of Innovation and Entrepreneurship 1(2), 1-14. https://doi. org/10.1186/2192-5372-2-15

Gupta, R., 2018, 'Entrepreneurship, national culture \& firm growth', Theoretical Economics Letters 8(7), 1401-1411. https://doi.org/10.4236/tel.2018.87090

Hallward-Driemeier, M., 2013, Enterprising women: Expanding economic opportunities in Africa, Africa Development Forum, Washington, DC, viewed 20 July 2018, from https://openknowledge.worldbank.org/handle/10986/13785 License: CC BY 3.0 IGO.

Hannum, K.M., Deal, J., Howard, L.L., Lu, L., Ruderman, M.N., Stawiski, S. et al., 2011 Emerging leadership in nonprofit organisations: Myths, meaning, and motivations, Center for Creative Leadership, Greensboro, NC

Haslam, S.A. \& McGarty, C., 2014, Research methods and statistics in psychology, 2nd edn., Sage, London.

Heikkilä, M., Bouwman, H., \& Heikkilä, J., 2018, 'From strategic goals to business model innovation paths: An exploratory study', Journal of Small Business and Enterprise Development 25(1), 107-128 https://doi:10.1108/JSBED-03-2017-0097 
Hennink, M., Hutter, I. \& Bailey, A., 2010, Qualitative research methods, Sage, London.

Hewitt, L.M.M., 2017, 'Entrepreneurial orientation as one construct and the moderating effect of internal control measures', in Central University of the Free State, Proceeding of the 1st International Conference on Entrepreneurship Development, Harlow, pp. 308-322.

Hewitt, L.M.M. \& Janse Van Rensburg, L.J., 2020, 'The role of business incubators in creating sustainable small and medium enterprises', The Southern Journal of Entrepreneurship and Small Business Management 12(1), a295. https://doi. org/10.4102/sajesbm.v12i1.295

Hewitt, L.M.M. \& Janse van Rensburg, L.J., 2018, From Start-Up Entrepreneur to Entrepreneurial Leader - A Conceptual Model, University of Johannesburg, Johannesburg.

Howitt, D., 2019, Introduction to qualitative research methods in psychology. Putting theory into practice, 4th edn., Pearson Education Ltd.

Irene, B.N.O., 2017, 'Women entrepreneurship in South Africa: Understanding the role of competencies in business success', Southern African Journal of Entrepreneurship and Small Business Management, viewed 12 July 2018, from https://sajesbm.co.za/index.php/sajesbm/article/view/121/111.

Isenberg, D., 2011, Introducing the entrepreneurship ecosystem: Four defining characteristics, March 25, 2011, viewed 10 July 2018, from https://www.forbes. com/sites/danisenberg/2011/05/25/introducing-the-entrepreneurshipecosystem-four-defining-characteristics/\#3104e9445fe8.

Jaques, E. \& Clement, S.D., 1991, Executive leadership, Cason-Hall, Virginia.

Jette, D.J., Grover, L. \& Keck, C.P., 2003, ‘A qualitative study of clinical decision making in recommending discharge placement from the acute care setting', Physical Therapy 83(3), 224-236. https://doi.org/10.1093/ptj/83.3.224

Johnsson, L., Eriksson, S., Karolinska, G.H. \& Hansson, M.G., 2014, 'Making researchers moral: Why trustworthiness requires more than ethics guidelines and review', Research Ethics 10(1), 29-46. https://doi.org/10.1177/1747016113504778rea. sagepub.com

Joseph, M.S. \& Unnikrishnan, A., 2016, 'Relationship bonding strategies and customer retention: A study in business to business context', IOSR Journal of Business and Management, International Conference on Emerging Trends in Engineering \& Management e-ISSN: 2278-487X, p-ISSN: 2319-7668, 38-44, viewed 01 April 2019, from http://www.iosrjournals.org/iosr-jbm/papers/ICETEM/Vol.\%201\%20 Issue \%201/MBA-7-38-44.pdf.

Kendall, J.E. \& Kendall, K.E., 2012, 'Storytelling as a qualitative method for IS research: 'Heralding the heroic and echoing the mythic', Australasian Journal of Information Systems 17(2), 161-187. https://doi.org/10.3127/ajis.v17i2.697

Kezar, A., 2004, Philosophy, leadership and scholarship; confucian contributions to a leadership debate, University of Southern California, Los Angeles.

Korstjens, I. \& Moser, A., 2018, 'Series: Practical guidance to qualitative research. Part 4: Trustworthiness and publishing', European Journal of General Practice 24(1), 120-124. https://doi.org/10.1080/13814788.2017.1375092

Korunka, C., Kessler, A., Frank, H. \& Lueger, M., 2011, 'Conditions for growth in oneperson start-ups: A longitudinal study spanning eight years', Psicothema 23(3), $446-452$.

Kronz, E., Sinar, E. \& Mitchell, S., 2014, 'Ready-now leaders: Meeting tomorrow's leadership challenges in multinational companies', in Global Leadership Forecast 2014-2015. The Conference Board; Development Dimensions International (DDI), Pittsburgh.

Kuratko, D. \& Audrestch, D., 2009, 'Strategic entrepreneurship: Exploring differen perspectives of an emerging concept', Entrepreneurship Theory and Practice 33(1), 1-17. https://doi.org/10.1111/j.1540-6520.2008.00278.x

Kuratko, D.F., 2007, 'Entrepreneurial leadership in the 21st century', Journal of Leadership and Organizational Studies 13(4), 1-11. https://doi.org/10.1177/1071 7919070130040201

Kyrgidou, L.P. \& Hughes, M., 2010, 'Strategic entrepreneurship: Origins, core elements and research directions', European Business Review 22(1), 43-63. https://doi. org/10.1108/09555341011009007

Kyrgidou, L.P. \& Petridou, E., 2011, 'The effect of competence exploration and competence exploitation on strategic entrepreneurship', Technology Analysis \& Strategic Management 23(6), 697-713. https://doi.org/10.1080/09537325.2011. 585040

Lain, J., 2016, Job Flexibility and Occupational Selection: An Application of Maximum simulated likelihood using data from Ghana, CSAE Working Papers, No. 34, Center for the Study of African Economies, Oxford.

Leminen, S. \& Westerlund, M., 2012, 'Categorizing the growth strategies of smal firms', Technology Innovation Management Review, viewed 20 May 2018, from https://timreview.ca/sites/default/files/article_PDF/LeminenWesterlund TIMReview_May2012_0.pdf.

Lincoln, Y.S. \& Guba, E.G., 1985, Naturalistic inquiry, Sage, Newbury Park, CA.

Loh, J., 2013, 'Inquiry into issues of trustworthiness and quality in narrative studies: A perspective', The Qualitative Report 2013, 18(Article 65), 1-15, viewed 17 Octobe 2020, from https://www.researchgate.net/profile/Jason_Loh/publication/260312062 Inquiry_into_Issues_of_Trustworthiness_and_Quality_in_Narrative_Studies_A_ Perspective/links/0c960530c1a8e125b0000000.pdf.

Lundberg, O. \& Richards, M.D., 1972, 'A relationship between cognitive style and complex decision-making: Implications for business policy', Academy of Management Proceedings 1972(1), 95. https://doi.org/10.5465/ambpp.1972.4981320

Mackay, A. \& Gass, S.M., 2016, Second language research, methodology and design, 2nd edn., Routledge, New York, NY
Mason, M., 2010, 'Sample size and saturation in PhD studies, using qualitative interviews [63 paragraphs]', Forum Qualitative Sozialforschung/Forum: Qualitative Social Research 11(3), Art. 8, viewed 08 February 2019, from http://nbn-resolving. de/urn:nbn:de:0114-fqs100387.

Mastercard, 2017, Mastercard Index of Women Entrepreneurs 2017, Mastercard, viewed 20 July 2018, from https://newsroom.mastercard.com/mea/files/2017/03/ Report-Mastercard-Index-of-Women-Entrepreneurs-2017-8-Mar2.pdf.

Mateev, M. \& Anastasov, Y., 2010, 'Determinants of small and medium sized fast growing enterprises in Central and Eastern Europe: A panel data analysis', Financial Theory and Practice 34(3), 269-295.

Mazzarol, T., 2014, 6 Ways Governments Can Encourage Entrepreneurship, World Economic Forum, University of Western Australia, viewed 13 July 2018, from https://www.weforum.org/agenda/2014/12/6-ways-governments-canencourage-entrepreneurship/.

McGoldrick, P., 2002, Retail marketing, 1st edn., McGraw Hill, New York, NY.

Meyer, N., 2018, 'Research on female entrepreneurship: Are we doing enough?', Polish Journal of Management Studies 17(2), 158-169. https://doi.org/10.17512/ polish Journal of $M$

Nesbitt-Ahmed, Z., 2017, The Road to Women Economic Empowerment: Thinking about Women-Owned Enterprises in Nigeria, February 23, 2017, February/March 2017, vol. 1(1), viewed 20 May 2017, from https://republic.com.ng/vol1-no1-2/ the-road-to-women-economic-empowerment/.

Ngugi, F., 2017, Uganda shines with highest number of women entrepreneurs, Face 2 Face Africa, viewed 15 July 2018, from https://face2faceafrica.com/article/ women-entrepreneurs-uganda.

Nieuwenhuizen, C., 2014, Basics of entrepreneurship, 3rd edn., Juta \& Company (Pty) Ltd., Cape Town.

O'Connor, C. \& Joffe, H., 2020, 'Intercoder reliability in qualitative research: Debates and practical guidelines', International Journal of Qualitative Methods 19, 1-13. https://doi.org/10.1177/1609406919899220

O'Reilly, M. \& Parker, N., 2012, 'Unsatisfactory saturation: A critical exploration of the notion of saturated sample sizes in qualitative research', Qualitative Research Journal 13(2), 1-8, 190-197. https://doi.org/10.1177/1468794112446106

Odebrecht, C.N, 2013, 'Women, Entrepreneurship and the Opportunity to Promote Development and Business', in Golubski, C. (ed.), Interprising Solutions: The Role of the Private Sector in Eradicating Global Poverty, pp. 31-39, The 2013 Global Economy and Development, Brookings Institution, Washington, viewed 07 September 2019, from https://www.academia.edu/33313084/Women_Entrepreneurship_and the https://www.academia.edu/33313084/Women_Entre
Opportunity to Promote Development and Business.

Ohtsubo, Y. \& Rapoport, A., 2006, 'Depth of reasoning in strategic form games', Journa of Socio-Economics 35(1), 31-47. https://doi.org/10.1016/j.socec.2005.12.003

Panneerselvam, R., 2018, Research methodology, 2nd edn., PHI Learning Ltd., Delhi.

Ponelis, S.R., 2015, 'Using interpretive qualitative case studies for exploratory research in doctoral studies: A case of information systems research in small and medium enterprises', International Journal of Doctoral Studies 10, 535-550, viewed 29 April 2021, from http://ijds.org/Volume10/IJDSv10p535-550Ponelis0624.pdf.

Potter, J., Halabisky, D. \& Hannig, S., 2016, Policy brief on women's entrepreneurship, OECD Local Economic and Economic Development (LEED) and Luxemburg Publications Office of the European Union, Luxemburg.

Price Water House Coopers (PWC), 2014, The future of work: A journey to 2022 viewed 06 May 2017, from www.pwc.com/gx/en/managing-tomorrows-people/ future-of-work/assets/pdf/future-of-work-reportv23.pdf.

Ramaswami, R. \& Mackiewicz, A., 2009, The ground breakers series: Driving business through diversity. Scaling up why women-owned businesses can recharge the global economy, Ernst \& Young, London.

Rick, S., 2018, Growth strategies in business. Small business. Business planning and strategy, viewed 20 June 2018, from http://smallbusiness.chron.com/growthstrategies-business-4510.htm

Ridder, H., 2017, 'The theory contribution of case study research designs', Business Research 10, 281-305. https://doi.org/10.1007/s40685-017-0045-z

Rugene, J., 2015, 'Kenya gains recognition in New York for women empowerment', The Daily Nation, Thursday, 19 March 2015, viewed 15 May 2018, from https:// www.nation.co.ke/news/Kenya-praised-NY-women-status/1056-26581364yw1wwz/index.html.

Saunders, M., Lewis, P. \& Thornhill, A., 2009, Research methods for business students, 5 th edn., Pearson Education Limited, New York, NY.

Schindehutte, M. \& Morris, M.H., 2009, 'Advancing strategic entrepreneurship research: The role of complexity science in shifting the paradigm', Entrepreneurship Theor and Practice 33(1), 241-276. https://doi.org/101111/j.1540-6520.2008.00288.x

Seo, Y.W. \& Lee, Y.H., 2019, 'Effects of internal and external factors on business performance of start-ups in South Korea: The engine of new market dynamics' International Journal of Engineering Business Management 11(4), 1-12. https:// doi.org/10.1177/1847979018824231

Shenton, A.K., 2004, 'Strategies for ensuring trustworthiness in qualitative research projects', Education for Information 22(2004), 63-75, viewed 17 October 2020, from https://www.researchgate.net/profile/Andrew_Shenton2/publication/228708239 Strategies_for_Ensuring_Trustworthiness_in_Qualitative_Research_Projects/ links/56cd506808ae85c8233bc986/Strategies-for-Ensuring-Trustworthiness-inQualitative-Research-Projects.pdf?origin=publication detail.

Shirokova, G., Bogatyreva, K. \& Beliaeva, T., 2015, 'Entrepreneurial orientation of Russian firms: The role of external environment', Foresight and STI Governance 9(3), 6-25. https://doi.org/10.17323/1995-459x.2015.3.6.25

Shmailan, A.B., 2016, 'Compare the characteristics of male and women entrepreneurs. An explorative study', Journal of Entrepreneurship \& Organisation Management 5, 4. https://doi.org/10.4172/2169-026X.1000203 
Singer, S., Herrington, M. \& Menipaz, E., 2018, Global entrepreneurship monitor Global Report 2017/2018, Global Entrepreneurship Research Association (GERA) Babson College, Massachusetts, ISBN-13: 978-1-939242-10-5.

Sniukas, M., Lee, P. \& Morasky, M., 2016, The DNA of new growth: Finding and seizing new growth opportunities through strategic innovation, John Wiley \& Sons, Incorporated, Hoboken, NJ.

Snyder, H., 2019, 'Literature review as a research methodology: An overview and guidelines', Journal of Business Research 104(2019), 333-339. https://doi. org/10.1016/j.jbusres.2019.07.039

Soini, H., Kronqvist, E.L. \& Huber, G.L., 2011, 'Epistemologies for qualitative research', Qualitative Psychology Nexus 8, 1-175.

Sriram, V. \& Mersha, T., 2010, 'Stimulating entrepreneurship in Africa', World Journal of Entrepreneurship. Management and Sustainable Development 6(4), 257-272. https://doi.org/10.1108/20425961201000020

Sutton, J. \& Austin, Z., 2015, 'Qualitative research: Data collection, analysis and management', The Canadia Journal of Hospital Pharmacy 68(3), 226-231. https:// doi.org/10.4212/cjhp.v68i3.1456

Taylor, S.J., Bogdan, R. \& DeVault, M., 2016, Introduction to qualitative research methods: A guidebook and resource, 4th edn., John Wiley and Sons, Hoboken, NJ.

Thomas, D.R., 2003, A general inductive approach for qualitative data analysis, Thomas School of Population Health, University of Auckland, viewed 15 June 2018, from http://frankumstein.com/PDF/Psychology/Inductive \%20Content\%20Analysis.pdf.

Tvedten, K., Wendelboe, M. \& Jeppesen, S., 2012, Understanding the rise of African business. In Search of an Analytical Framework, CBDS Working Paper Series, Center for Business and Development Studies, Copenhagen Business School, Copenhagen.

Uhl-Bien, M., 2006, 'Relationship leadership theory: Exploring the social processes of leadership and organizing', The Leadership Quarterly 17(6), 654-676.

Unger, J.M., Keith, N., Hilling, C., Gielnik, M.M. \& Frese, M., 2009, 'Deliberate practice among South African small business owners: Relationships with education, cognitive ability, knowledge, and success', Journal of Occupational and Organizational Psychology 82(1), 21-24. https://doi.org/10.1348/096317908X 304361

Ungerer, M., Ungerer, G. \& Herholdt, J., 2016, Crystallising the strategic business landscape, Knowledge Resource Publishing, Randburg.
Uwe, F., 2015, Introducing research methodology: A beginner's guide to doing a research project, 2 nd edn., Sage, London.

Verhoef, G., 2017, The history of business in Africa; complex discontinuity to emerging markets, Department of Accountancy University of Johannesburg Auckland Park, Springer International Publishing, Cham.

Vining, A.R., 2011, 'Public agency external analysis using a modified "Five Forces" framework', International Public Management Journal 14(1), 63-105. https://doi. org/10.1080/10967494.2011.547819.

Walliman, N., 2011, Research methods, the basics, Routledge, London.

Wang, C.C. \& Geale, S.K., 2015, 'The power of story, narrative inquiry as a methodology in nursing research', International Journal of Nursing Sciences 2(2), 195-198. https://doi.org/10.1016/j.ijnss.2015.04.014

Wanjala, E., 2018, 'Africa accounts for more women entrepreneurs - Report', The Star Newspaper, 10 February 2018, viewed 21 May 2018, from https://www.the-star. co.ke/news/2018/02/10/africa-accounts-for-more-women-entrepreneursreport_c1712320.

Wheeler, C., Ibeh, K.I.N. \& Dimitratos, P., 2008, 'UK export performance research: Review and implications', International Small Business Journal 26(2), 207-239. https://doi.org/10.1177/0266242607086574

White, D.N., Oelke, N.D. \& Friesen, N., 2012, 'Management of a large qualitative data set: Establishing trustworthiness of the data', International Journal of Qualitative Methods11(3), viewed 18 October 2020, from https://journals.sagepub.com/doi/ pdf/10.1177/160940691201100305.

Williams, M., 2000, 'Interpretivism and generalisation', Sociology 34(2), 209-224. https://doi.org/10.1177/S0038038500000146

World Bank Group, 2019, Profiting from parity: Unlocking the potential of women's business in Africa, World Bank, Washington, DC, viewed 21 May 2018, from https://openknowledge.worldbank.org/handle/10986/31421.

Yang, M., Evans, S., Vladimirova, D. \& Rana, P., 2014,' Sustainable value analysis too for value creation', Asian Journal of Management Science and Applications 1(4), 312-332. https://doi.org/10.1504/AJMSA.2014.070649.

Yin, R.K., 2008, Case study research: Design and methods, 4th edn., Sage, London.

Yuki, G., 2002, Leadership in organizations, 5th edn., Prentice Hall Inc., Hoboken, NJ. 